\title{
AS ORIGENS HISTÓRICAS DE UM POEMA ÉPICO (1)
}

Um dos principais episódios da canção de Gesta conhecida pelo nome de Moniage Guillaume é um combate singular que pôs frente a frente, sob os muros de París, Guilherme de Orange e o gigante Iscré.

Essa lendária narração baseia-se num dado histórico que data do fim do século $X$, e é possivel acompanhar-lhe as sucessivas transformações no decorrer dos dois séculos que se lhe seguiram.

\section{I - O DADO HISTORICO}

A menção de um combate singular entre dois campeões, sob os muros de París, aparece na relação que Richer (2), monge de Saint-Rémy de Reims, nos deixou da expedição que o imperador germânico Otão II dirigiu em 978 contra Lotário, rei da França. A história de Richer abrange o período compreendido entre 888 e 995. Foi composta quando Gerberto era arcebispo de Reims, isto é, entre 991 e 998. Richer foi, pois, contemporâneo de boa parte dos acontecimentos por êle narrados e, particularmente, dessa invasão que chegou quase à vista de París. Sua sóbria narrativa dêsse acontecimento é confirmada, ou ùtilmente completada, no que se refere às operações diante de París, por duas crônicas da primeira metade do século XI, mais sumárias, denominadas Gesta pontificum cameracensium (3) e as Historiae de Raul Glaber (4).

O sentido de certos pormenores dados por êsses textos pode escapar-nos, se não imaginarmos, antes de tudo, os sentimentos do imperador Otão no momento em que empreendeu essa campanha. Movia-o menos a ambição que a impaciência de vingar-se de um ultraje que o ferira no mais íntimo do seu amor-próprio alguns meses antes.

O rei da França, Lotário, com a intenção de recuperar a Lorena, lançara contra êle, no comêço do verão dêsse mesmo ano de 978, uma súbita ofensiva, cujos preparativos haviam sido cui-

\footnotetext{
(1). - Texto francês traduzido pelo licenciado Moisés Rovner.

(2): - Richer, Histoire de France (88-995). Edição e tradução de R. Latouche, em Les Classiques de I'histoire de France au Moven Age, 1930, 2 volumes.

(3). - Monumenta Germaniae Historica, Scriptores, VII, p. 393-489.

(4). - Ibid.; p. 52 e seguintes, e a edição de Maurice Prou, 1886 (Coleção de textos utilizados no estudo e ensino de História).
} 
dadosamente dissimulados. Em conseqüência do efeito de surprêsa, atingira a própria residência do imperador, o palácio de Aixla-Chapelle. Otão por pouco não foi feito prisioneiro, com a imperatriz e a côrte. Quando the "disseram e repetiram que Lotário já estava às portas (da cidade)", diz Richer em sua narrativa (III, 70-71), Otão teria respondido que não podia decidir-se a acreditar nisso enquanto não o verificasse com os seus próprios olhos. Trouxeram, então, alguns cavalos, e Otão partiu a fim de comprovar a afirmação. Reconheceu Lotário, que avançava com vinte mil homens. Pensou, então, em resistir ou em recuar momentâneamente, com a intenção de voltar, depois, com numeroso exército. Finalmente, diante de Lotário, que o perseguia, não pôde resistir. Retirou-se, pois - não sem derramar lágrimas - com sua mulher, Teófana, e com os grandes do reino, abandonando o palácio e as insignas reais.

"Lotário chegou com suas tropas, firmemente decidido a aprisionar Otão; certamente o teria conseguido se os comboios do exército não o tivessem estorvado em sua marcha; porque, se êle tivesse chegado na véspera, antes da partida de Otão, teria podido fazê-lo prisioneiro ou matá-lo. O palácio é ocupado pelos inimigos; as mesas reais são derrubadas; os bagageiros do exército pilham os víveres; as próprias insignas reais, arrancadas de seus esconderijos, são levadas. A águia de bronze, que Carlos Magno fixara no ápice do palácio em atitude de vôo, é colocada em direção ao leste. Os germanos tinham-na voltado para o oeste, a fim de, simbòlicamente, indicar que sua cavalaria poderia bater os franceses quando entendesse. Após êsse inútil ataque, Lotário fêz voltar $\circ$ seu exército, sem fazer reféns, nem concluir a paz, porque nutria a esperança de voltar mais tarde".

Tendo Lotário partido, Otão prepara-se imediatamente para vingar-se da intolerável ofensa que fôra feita à sua honra. À custa de muitas liberalidades e concessões, consegue o inteiro apôio dos seus vassalos e, assim, reune exército tão grande que a memória humana nunca registrara outro igual (5). Só a cavalaria se cumpunha, no dizer de Richer (III, 74), de trinta mil homens. Manifestando, ao mesmo tempo, confiança em sua fôrça de desprêzo pelos processos pelos quais Lotário conseguira a vantagem da surprêsa, previne-o de que invadirá o seu reino a $10^{\circ}$ de outubro seguinte, e põe-se em marcha no dia pré-determinado. Como Lotário não tivesse podido reunir em tempo hábil um exército bastante numeroso, retira-se até o Sena. Aí, vai encontrar "gemendo", diz Richer, o duque de França, Hugo Capeto, para pedir-lhe socôrro. Ao passo que êste se encerra em París a fim de defender a passagem

(5). - ".. tantas copias exercitum movit ut nemo tantum postea vel ante se vidisse potuerit." (Gesta pontificum cameracensium, M. G. H. SS. VII, p. 440), Raul Glaber (M. G. H. SS. VII, p. 54) avalia êsse exército em sessenta mil homens e mais. Veja-se F. Lot, Les derniers Carolingiens, 1891 , p. 98. 
do rio, Lotário atinge Etampes, onde convoca seus vassalos com as respectivas tropas. Entre os grandes que atenderam ao seu apêlo encontrava-se o conde de Anjou, Godofredo Grisegonelle. "Durante êsse tempo, continua Richer (III, 74), Otão avançou apressadamente com o seu exército; pilhou e incendiou o domínio real de Attigny. Ao atravessar o território da cidade de Reims, fêz grandes devoções a São Remígio; atravessou, também, a cidade de Soissons, onde venerou São Medardo, e depois devastou quase que completamente $o$ palácio de Compiègne... Chegou, finalmente, às margens do rio Sena, onde o seu exército acampou, diante de París". Nâo tentou, porém, transpor o rio: "Separados pelo curso do Sena, diz Richer (III, 75), os dois exércitos não podiam entrar em contacto". Era preciso que París e a margem esquerda tivessem sido firmemente defendidas por Hugo Capeto e pelas tropas de Lotário para que o imperador germânico tivesse sido obrigado a interromper a execução de tão almejada vingança.

Aqui se situa, na narrativa de Richer (III, 76), um episódio que a memória do povo iria consetvar. Reproduzo a tradução de Roberto Latouche:

Enquanto os dois exércitos permaneciam na expectativa e a preocupação da vitória os absorvia, um gemano, confiando no seu valor e em sua fôrça, avançou armado, sòzinlıo, para bater-se. Foi até à ponte, cujas portas eram providas de barras e pregos de ferro, para tentar um combate corpo a corpo. Por diversas vêzes desafiou o inimigo a combate singular. Ele já se havia excedido em injúrias ofensivas aos franceses, sem que ninguém the respondesse, quando as sentinelas con aram ao duque e a outros grandes que vieram em pequeno número que estava às portas um homem que se oferecia para bater-se em combate singular. Esse homem, acrescentavam, atormentava os grandes com as suas invectivas e palavras injuriosas, c não se retirará enquanto nāo fôr enfrentado em combate singular ou não tiver qucbrado as por'as para introduzir todo o exército. De acôrdo com os grandes, o duque julga a ofensa intolcrável; convida os vassalos (6) ou os jovens soldados a repelirem êsse louco furioso e a se cobrirem de gloria, desagravando de tal mancha sua reputição.

Não tardou que muitos dêles, chcios de ardor, se apresentassem para enfrentar o homem. Entre êles, escolheram um que avançou para a luta. Ofereceram-lhe uma recompensa pela sua bravura. Depois, tiraram as barras e as portas se abriram. Os dcis adversários marcharam um contra o outro. Protegidos pelos seus escudos que os defendiam dos dardos, trocaram, em tom furioso, algumas grosseiras injúrias. Em seguida, o germano arremessou um dardo que, em violento golpe, perfurou o escudo do francês. Desembainhando, então, sua espada, ameaçava investir sôbre êle, quando o francês o trespassou com um dardo atirado de lado e o matou. Vitorioso, o francês arrancou as armas ao inimigo, levou-as e ofereccu-as ao duque. Esse corajoso homem reclamou sua recompensa e obteve-a.

(6). - A mes ver, vassalos nāo traduz exatamente a palavra milites; proponho que se deixe a esta última o seu sentido próprio: soldados. 
Nessa passagem se encontra a confirmação de uma notícia dada já no século IX por Abbon em seu poema sôbre o cêrco de París pelos normandos: o que, ainda nessa época, se denomina porta de París é a porta fortificada que domina a entrada da ponte do lado de fora. O guerreiro germânico de que fala Richer pertence a um exército acampado ao norte de París. A porta da ponte, diante da qual êle se apresentou, está, portanto, situada sôbre a margem direita, adiante da Grande Ponte, no local da atual praça do Châtelet. E' a porta que, em 885 , sofrera o primeiro assalto dos normandos.

Ainda como na época de Abbon, o valor do observatório de Montmartre impõe-se à atenção dos chefes. Sabemos, pelos Gesta pontificum cameracensium, de que modo o imperador Otão utilizou-o pela última vez, quando, após haver em vão estacionado diante de París por várias semanas, resolveu regressar. Reuniu, diz o autor dessa crônica, o maior número de clérigos que pôde encontrar e, tendo feito com que subissem à colina de Montmartre, ordenou-lhes que entoassem com tôda a fôrça uma Aleluia para celebrar a sua vitória (7). Esperava que suas vozes chegassem até o Sena e que, se não tivessem scfrido todo o pêso do seu poder, os parisienses ouviriam, ao menos, o seu canto de triunfo. Singular emprêsa, certamente: compreende-se, porém, muito bem que ela se tenha apresentado ao espírito de um homem de guerra, nesses tempos em que a idéia de observatório militar se associava naturalmente à de sinal sonoro. Na última parte do seu poema, Abbon nos mostra como Eudes, antes de um encontro com uma tropa de normandos, em 888, em Montfaucon d'Argonne, sobe a uma altura em que descobre os movimentos do inimigo, e, daí, faz com que seu côro dirija aos seus, por sons "ora cheios, ora quebrados", (8) apelos convencionados.

As crônicas contemporâneas da expedição de Otão II contra Lotário confirmam, em seu total, as informações dadas pelo poema de Abbon acêrca do local da porta de París e do interêsse que, em tempo de guerra, tinha o belvedere de Montmatre.

Pode-se separar dêste dado histórico os prolongamentos épicos ou lendários (9) com que as gerações posteriores deviam enriquecê-lo. A êste respeito, um dos episódios narrados por Richer devia ter grandes destinos literários: é o combate singular, diante

(7). - "Deinde vero ad pompandam vicioriae suae floriam Huboni, qui Parisius residebat. . accitis quam plurimum clericis ALLELUIA TE MARTIRUM in loco qui dicitur Mons Martirum in tantum elatis vocibus decantari percepit ut attonitis auribus ipse $H_{u g 0}$ et omnis Parisiorum plebs miraretur." ( $M . G$. H. SS. VII, p. 441). F. Lot, Les detniers Carolingiens, 1891 , p. 102 .

(8). Canto II, verso 515.

(9). - Eles foram estudados na França por Ferdinand Lot, Geoffroi Grisegonelle dans I'épopée (România, XI, 1890, p. 377-393) e Notes sur le Moniagée Guillaume (Ibid., XXVI, 1897, p. 481-494), e por W. Cloètta, Les deux rédactions en vers du Moniage Guillaume, 1911, (Société des Anciens textes françain), t. II, p. 134 e seguintes. Veja-se, também, em R. Latouche, ediçāo e tradução Histoire de la France de Richer (Les Classiques de l'histoire de France au Moyen Age, 1930-1937), t. II, a importante nota 3 da página 93 
da porta de París, entre um homem do exèrcito de Otăo II e um dos soldados de Hugo Capeto. Um historiador alemão considerou tal narrativa como invenção do fanatismo patriótico francês. Outro historiador considera-o verossimil. Ferdinand Lot (Les derniers Carolingiens, p. 101) menciona êsse combate singular como um fato histórico. Não me parece que a autenticidade da narrativa possa ser posta em dúvida. O episódio, tal como o narra Richer, está inteiramente de acôrdo com o que sabemos acêrca dos sentimentos do imperador germânico. Otão II quer tirar de Lotário uma desforra de amor-próprio, e, não tendo podido infligir-lhe a derrota decisiva, que considerava como certa, procura humilhá-lo por manifestações espetaculares de que a Aleluia de Montmartre cferece cloqüente testemunho. Justamente na forma em que é feita, esta provocação ao combate singular não é de natureza a dar aos franceses a impressão de que os alemães os consideram nobres adversários. O campeão que lhes é enviado é, segundo a própria expressão de Richer, um quidam, cujas provocações são grosseiras. A aventura é conduzida de tal modo, que deve inevitàvelmente confundir Hugo Capeto e os senhores que o cercam: ou ouvirão intoleráveis insultos que, se não lhes ferem diretamente os ouvidos, thes serão transmitidos pela narração dos espias, o que lhes será ainda mais desagradável, ou passará pelo ridículo đe um duelo com um homem que não é de sua classe. E se êsse duelo resultar em vitória para o alemão, sua humilhação será sem precedente. Não é, pois, de se admirar que, dos grandes aos quais o campeão germânico dirige suas injúrias, nenhum se apresente para aceitar o desafio. O único recurso é pedirem a seus inferiores, simples soldados (milites) que os desembaracem, mediante recompensa, daquele a quem chamam de louco furioso. Não há, pois, dúvida de que, nesta passagem da narrativa de Richer, o têrmo milites - o próprio autor prová-lo-á - designa o escalão inferior da hierarquia militar.

E', provàvelmente, a humildade da condição do vencedor que explica o fato de o seu nome nos ser desconhecido. Já na época em que Richer escrevia, isto é, apenas dezoito anos após o acontecimento, havia incerteza quanto à identidade do herói ou quanto à oportunidade de transmitir seu nome à posteridade. E' a própria pena de Richer que o atesta. A biblioteca de Bamberg, na Baviera, possui o manuscrito autografado, ou, pelo menos, corrigido pela mão do autor. Vêem-se nêle, distintamente, as correções que. fora de tempo, fêz em sua primeira redação. Ora, precisamente, êle corrigiu, em vários lugares, sua narrativa do combate singular. A passagem em que Hugo Capeto e os grandes se dirigem a seus homens para exortá-los a aceitaram o desafio do alemão era, na sua primeira redação: milites hortatur ut canem latrantem repellant, convida os soldados a repelirem êsse cão ladrador; e torna-se, depois da correção: milites (vel tirones) horta- 
tur ut furentem repellant, convida os soldados (ou os jovens recrutas) a repelirem êsse louco furioso.. $O$ interêsse principal do retoque não está, certamente, na escolha do qualificativo considerado apropriado ao campeão germânico, e sim na adição das palavras vel tirones acrescentadas à palavra milites. Tiro significa jovem soldado, novo recruta. Richer retocou, pois, seu texto, com o fim de nele introduzir um matiz que dá uma idéia ainda mais modesta da categoria a que pertence o campeão francês. E, sobretudo, riscou, para eliminá-1o de sua redação defintiva, o nome que dera como sendo o do herói: Ivo.

O homem recebera, após sua brilhante ação, a recompensa que seus chefes lhe haviam prometido; mas a glória, que, entretanto, merecia, não o acompanhava. Menos de vinte anos mais tarde, o historiador Richer, a quem não deviam faltar os meios de informação sôbre um acontecimento que ocorrera durante a sua vida. numa região relativamente próxima a seu mosteiro de Reims, que, pelo menos, êle atravessara por ocasião de sua viagem a Chartres, em 991 (10), julgava, depois de refletir, que melhor seria apreseñtar como anônima essa brilhante ação. Esse surpreendente silêncio, mantido em tôrno do autor de proeza tão pouco comum, deixava campo livre às imaginações, e até as solicitava, tanto mais que, sendo a vitória do campeão francês narrada como a única façanha militar notável verificada diante de París no decorrer dessa campanha, podia aparecer como a causa da retirada de Otão II. Sabe-se que essa retirada suscitou na França entusiasmo muito vivo, de que Ferdinand Lot (11) teve um admirável testemunho na própría redação da data de um foral de Tours: Data autem haec auctoritas mense marcio, sub magno rege Hlotario anno scilicet $X X V I$, quando impetum fecit contra Saxones et fugavit imperatorem. Nem por isso o combate singular deixava de se revestir de maior importância, e, como a tradição histórica silenciava o nome de quem dêle saíra vencedor, formaram-se lendas com o fim de atribuir a glória do àcontecimento a êste ou aquêle personagem a quem se desejava honrar ou engrandecer. Tais lendas, pelo menos as que conhecemos, não são, como se verá, criações do gênio popular. Os seus principais episódios foram imaginados e hàbilmente combinados por eruditos.

$$
\text { II — OS HISTORIOGRAFOS CORTESÃOS }
$$

Alguns clérigos ligados ao serviço das grandes casas senhoriais, ou interessadas em merecer os seus favores, aplicaram-se a

(10). - R. Latouche, Introdução à edição de Richer, Histoire de France, t. I, p. VIII. (11): - Geoffroi Grisegonelle dans l'épopée (România, XIX, 1890, p. 392) e Les derniers Carolingiens, 1891 , p. 107. 
preencher, para maior glória de seus senhures, as lacunas da tra. dição histórica.

Segundo o cônego da catedral de Nantes, que, entre 1050 e 1059, escreveu a chamada crônica de Nantes (12), nenhuma dúvida resta quanto à identidade do vencedor do combate singular. E' aquêle a quem chama illuster princeps Alanus dux Britanniae cognomine Barbatorta: Alano Barbatorta, duque da Bretanha, morto já há muito tempo para que se pudesse algo acrescentar à história de sua vida sem ter-se que contar com as testemunhas oculares (13).

Uma vez admitida, porém, tal identificação obrigava a suprimir-se ou transformar-se, na tradição histórica, tôda espécie de coisas que a contradiziam, e, antes de tudo, uma incompatibilidade de caráter cronológico: Alano Barbatorta morreu em 952, vinte e seis anos antes da invasão de Otão II. Não viveu no reinado de Lotário, e sim no de Luiz IV de Ultramar. A fim de permitir a seu herói a participação no combate singular, o cônego de Nantes não hesita em situar a invasão de 978 no reinado de Luiz VI, e. por conseguinte, em colocar o exército germânico sob o comando de Otão I. Excetuado, porém, êsse grosseiro anacronismo, respeita, no que tem de essencial, o dado histórico relativo à série de acontecimentos em que se insere êsse combate: a marcha do imperator Othonius contra os franceses, à frente de um grande exército, o apêlo dirigido pelo rei, em aflição, a seus grandes vassalos, a suspensão da invasão diante de París, a derrota do campeão germânico, a retirada do imperador. Feito isto, era ainda necessário, para que Alano Barbatorta pudesse tornar-se o herói dêsse drama, eliminar uma incompatibilidade de caráter social, que resultava da personalidade do campeão alemão. O quidam germânico que Richer qualificava sucessivamente de cão ladrador e de louco furioso torna-se, na crônica de Nantes, imponente adversário, um superbus hostis digno de um grande senhor. Este saxão, como o chama um historiógrafo bretão, cumpriu um encargo do qual só poderia ser incumbido um homem capaz de representar dignamente o imperador. Da parte de Otão, chama os melhores e mais bravos franceses para um combate singular de que devia depender o destino do reino da França, que pertenceria- ao rei Luiz ou ficaria com Otão, conforme a vitória sorrisse a um ou outro dos dois campeões. A importância do que estava em jôgo e a qualidade do adversário justificavam, certamente, que um duque da Bretanha entrasse na liça.

Mas a ficção que eleva o campeão germânico à classe de um íntimo do imperador tem, entre outras, a conseqüência de fazer

(12) - Editada por R. Merlet, na Collections de textes pout servir à l'élutle et à l'enseignement de l'histoire, n.o 19; 1896.

(13). - Suas recordaçōes forneceram ao autor boa parte dos materiais por êle empregadog em sua história de Nantes durante a primeira metade do século onze. Assim, observa R. Merlet, "assinalando um estranho prodígio que se teria produzido em Nantes no govêrno do conde Judicael (992-1004), êle afirma ter tido conhecimento do mesmo por intermério de várias pessoas que o viram com os próprios olbos." (Ibid., introdữ̧̃o. p. XXVII-XXVIII). 
com que aparecessem como poltrões aquêles a quem o cronista denomina proceres et comites Franciae, isto é, os grandes que, em París, receberam o desafio sem aceitá-lo. Tendo Alano Barbatorta, diz. o cronista de Nantes, notado que vários dias se passaram sem que nenhum dos barões de París ousasse enfrentar o saxão para defender os direitos do rei sôbre o seu reino, teve grande vergonha disso e resolveu que êle mesmo cumpriria o que os outros grandes não tinham a coragem de fazer. Toma suas armas e seu cavalo, e, depois, na atitude representada pela palavra equitans (a cavalc) - pois é a cavalo que convém que se bata um grande senhor - empenha-se em luta contra o saxão, a quem não tarda em decapitar, diante dos dois exércitos, que, cada qual de seu lado, contemplam a cena.

Na crônica de Nantes permanece obscura uma passagem: é aquela em que Alano Barbatorta é representado preparando-se secretamente ( latenter) para o combate, e tendo o cuidado de dissimular sua marcha em direção ao saxão. Ao invés de fazer com que the abram, como ao histórico miles de Richer, a porta da extremidade da ponte, diante da qual o alemão vociferava seus insultos, o duque da Borgonha, para atingir o seu adversário, segue um itinerário diferente. Sobe o rio Sena, em barco, tendo a seu lado o cavalo, e vai ter à margem direita, muito acima da cidade, para que se não perceba a sua marcha. Semelhante ação causa surprêsa em uma narrativa da qual tôdas as partes concorrem para o engrandecimento do herói. Se é verdade, porém, que o cônego de Nantes - e o comêço de sua narrativa quase não permite duvidar-se de que não o tenha feito - levou em conta a resistência que a tradição histórica opunha a suas ficções, concebe-se que as palavras latenter... ne iter demonstraretur, que nada têm de vantajoso para o duque de Bretanha, aí tenham sido postas para se facilitar a resposta a quem quer que objetasse ao cônego a lembrariça do anonimato em que permanecera o vencedor do combate singular. Não se sabia quem estava em combate - poderá êle responder a seu contraditor - por que o duque atingira, sem ser visto, o prado em que se achava o saxão. Sem dúvida, não poderia durar essa situação, já que um dos objetivos da narrativa consiste em mostrar que o rei da França deve ao duque da Bretanha nada mais nada menos que o seu reino; é, porém, prolongada c mais possivel. Ainda após a vitória, o duque, por um motivo que não se compreende bem, toma o caminho diferente, pelo qual fôra ao combate. Encontra o barco na margem em que - prendera, isto é, rio acima, longe de París, e volta à cidade pelo rio. E' sòmente depois de ter chegado ao pôrto que sua glória aparece. Mostra, então, ao rei Luiz - que, por causa das necessidades dessa glória, o cronista afirma residir em París - a cabeça do inimigo vencido. 
Depois disso diz o cronista, Othonius imperator, valde perterritus, in patriam suam cum suo exercitu rediit tristis, sicque urbs parisiorum ab infestatione inimicorum suorum per manum Alani liberata remansit: "O imperador-Otão, muito atemorizado, voltou, com o exército, para o seu reino, tristemente. $\mathbf{E}$ foi assim que a cidade de París se livrou dos ataques do inimigo, pela ação de Alano" que, ao mesmo tempo, trabalhara magnificamente para a grandeza da casa da Bretanha.

Após o illuster princeps Alanus dux Britanniae, é um consul Andegavorum, isto é, um conde do Anjou, Godofredo Grisegonelle, que reclama para si próprio a glória que, em 978, merecera o obscuro soldado de Hugo Capeto. Graças aos cuidados de um ou de vários clérigos a serviço dos condes do Anjou, a história recebe as emendas e os complementos que a põem em condições de servir ao prestígio dessa poderosa casa: os Gesta consulum Andegavorum (14), no estado em que nos vieram às mãos, são, principalmente, a obra de um certo Tomaz que, na primeira metade do século doze, exercia as funções de notário e capelão da côrte dos condes do Anjou. Foi nomeado por um dêles prior de Nôtre-Dame de Loches, donde o nome de Tomaz de Loches, pelo qual é comumente chamado.

Sob certos aspectos, era a tarefa do historiógrafo angevino mais fácil que a do cônego de Nantes, pois o conde do Anjou, Godofredo Grisegonelle, que era preciso fazer sair vencedor do combate singular, participou efetivamente (15) da guerra de 978 . Foi êste um dos grandes vassalos que o rei Lotário chamou em seu socôrro, quando se refugiou em Étampes, diante da invasão do exército de Otão II; e quando o imperador tomou o caminho de regresso, Godofredo Grisegonelle participou ativamente, como porta-estandarte do rei, da perseguição às tropas germânicas.

Entretanto, a personagem de Otão II, cuja presença, diante de Godofredo Grisegonelle foi històricamente exata, é eliminada da narrativa; e isso não pode ser, em um erudito tal como Tomaz de Loches, efeito de ignorância. O senhor a serviço do qual exerce as funções de notário e capelão, Godofredo-o-Belo, conde do Anjou, casou-se, em 1127, com a viúva de um imperador romanogermânico, Matilde, que conserva seu título imperial. O próprio Tomaz de Loches figura como testemunha, com seu título de capellanus comitis andegavensis, por ordem da "imperatriz" Matilde (16). Como poderia o historiógrafo da côrte de Anjou, depois dêsse casamento que sela a união da dinastia angevina com a dinastia imperial, descrever uma cena em que se veria um conde de Anjou abater, em combate singular, um imperador da Alemanha, ou um de seus parentes, e decapitá-lo? Porque, para que se desse

(14). - Ediçäo de L. Halphen e R. Poupardin, Chroniques des comfes d'Anjout et des seigneurs d'Amboise, 1913, in Collections de textes pour servir a l'étude et l'ensigne-

ment de 'histoire.

(16). - L. Halphen e R. Poupardin, Chronique des comtes d'Anjou et des setgneurs d'Amboise, 1913 , p. XXIX, n. ${ }^{\circ} 1$. 
a Godofredo Grisegonelle um adversário digno dêle, era 0 chefe do exército inimigo que seria preciso fazer com que avançasse ao seu encontro. Se Tomaz de Loches não encontra o meio de substituir ao imperador Otão outro inimigo dos franceses, não poderá mais atribuir decentemente à casa de Anjou a glória do combate singular diante dos muros de París. París, porém, no decorrer de sua história, conheceu outros inimigos, e mais terríveis, pois eram pagãos: são os normandos, mais comumente chamados dinamarqueses. Para afastar a importuna lembrança da ativa participação de Godofredo Grisegonelle na humilhação de Otão II, nada se pode conceber de mais eficaz do que a evolução das grandes lutas contra os inimigos comuns da cristandade. Aquêle que Godofredo Grisegonelle vai encontrar diante de si é o chefe dos dinamarqueses, "homem de estatura e bravura prodigiosas; que, em língua francesa, se chama Haustuin", e que bem parece ser o famoso Hastings (17).

Tendo, dêsse modo, vencido, não sem esfôrço, o primeiro obstáculo, Tomaz de Loches vai encontrar, uma após outra, tôdas as dificuldades que o cônego de Nantes já encontrara em seu caminho. A mais simples delas, que se relaciona com o lugar de estada do rei, foi resolvida do mesmo modo: o rei Lotário, do qual diz a História que parara em Étampes, é instalado em París, a fim de poder ser testemunha ocular do combate singular.

O cronista angevino, porém, sentiu mais profundamente do que o seu antecessor nantês a dificuldade central, que resulta do silêncio mantido pela tradição histórica acêrca do nome do vencedor. Como pôde êsse nome passar despercebido aos contemporâneos? E, se é preciso que o herói seja um grande senhor, como admitir-se que tenha realizado êsse feito brilhante sem ter conhecido, logo depois, o mais belo triunfo com que possa sonhar um barão: as felicitações do rei diante da côrte reunida, e a concessão de um glorioso sobrenome, que relembraria à posteridade sua proeza?

E' significativo que o cronista angevino tenha recuado diante da idéia da denegação pura e simples da tradição histórica. Por mais amplas que sejam as liberdades por êle tomadas em outra parte com a História, não jugou poder esquivar-se à obrigação de impor a seu herói êsse anonimato que parece ter sido o traço mais popular da lembrança que se poderia guardar, então, na França, do cêrco de 978. Acaba-se de ver com que inabilidade o cônego de Nantes fêz $z$ essa inevitável concessão à História, valendo-se do advérbio latenter, que concorda tão mal quanto possível com as atitudes $e$ as intenções que êle empresta ao duque Alano Barba-

(17). - Ccnforme observa Ferdinand Lot (Geoffroi Grisegonelle dans I'épospéc, Romania, XIX, 1890, p. 388-389), o nome que os Anais de Saint-Bertin e os Anais de SaintWaast dāo ao chefe dinamarquês Hastings: Halstingus, pode tornar-se, em francès Haustuin. 
torta. O cronista angevino conseguiu mais verossimilhança fazendo com que, do comêço ao fim da ação, seu herói permanecesse fora de París, onde teria sido inevitàvelmente reconhecido. As provocações do campeão inimigo localizam-se, nos Gesta consulum Andegavorum, no momento em que Godofredo Grisegonelle, tocado, logo em seguida, pelo apêlo que o rei dirigiu a seus vassalos, está em caminho para París, distanciado, porém, ainda, dessa cidade. Foi ao chegar a Orleans que teve conhecimento do escândalo, e que decidiu que êle mesmo iria terminá-lo.

Neste ponto da narrativa, a dificuldade consiste em inspirarlhes a resolução de levar a efeito, secretamente, sua ação (volens se occultare). Consegue-o o cronista por meio de habilíssima invenção, que, ao mesmo tempo, lhe poupa o desgôsto de ter que representar os barões de París como covardes. O cônego de Nantes aceitara, com tôda a simplicidade, esta desagradável conseqüência da ficção. O angevino, porém, revela mais delicadeza. Se os grandes permaneceram, em París, imóveis diante do ultraje, explica êle, é porque o rei, tendo visto perecerem vários dos melhores entre êles, que tinham aceito o combate singular, proibiu-lhes aceitarem, daí por diante, os desafios do dinamarquês. E' essa interdição real que faz com que Godofredo Grisegonelle deva esconder-se para chegar até ao inimigo. Se seguisse o itinerário normal, atravessaria París de ponta a ponta, pois chega à cidade pela porta do sul, a da $\mathrm{Pe}-$ quena Ponte, ao passo que seu inimigo se mantém diante da porta oposta, na extremidade norte da Grande Ponte. Como, porém, êle vai transgredir uma ordem do rei, é-lhe impossível aparecer em París, onde, desde a porta, seria obrigado a dar-se a conhecer, em vista das senhas de tempo de guerra. Eis como se concatena, em função dessas diversas necessidades, a narrativa do cronista (expõe-se, aqui, resumidamente, o conteúdo):

Nessa época, o dinamarquês Hausten devastou por três anos as regiões marítimas da França e, finalmente, à frente de quinze mil dinamarqueses e saxões, foi ter com seus primos, que eran os condes de Flandres, Eduardo e Hilduino. Estava acompanhado de Hetelulfo, homem de estatura e bravura prodigioșas, que em francês se chama Haustuin (18). Com o auxílio dos flamengos, puseram a ferro e a fogo quase tôda a parte da França que se avizinha da Flandres, depois decidiram marchar sôbre París, espalhando o terror em sua passagen. Tendo atingido un belo e agradável vale entre Montmorency e París, decidiram passar aí algum tempo e tomaram o castelo de Montmorency, que fortificaram. O rei, atemorizado, e não tendo meios de travar batalha (porque os franceses, obrigados a refugiar-se por trás dos muros da cidade, não ousavam fazer uma sortida) convocon a París os seus vassalos de tôdas as par'es do seu reino. Cada dia, o dinamarquês Hetelulfo vinha insultar o exército francês diante de París, e pedir que um francês qualquer saísse para medir fôrças com êle. Depois de haver, porém, o mesmo

(18). - Edilvulf, rei dos anglo-saxōes, é conhecido na França pela acolhida que teve, em 855, da parte do rei Carlos-o-Calvo, com cuja filha se casou no ano seguinte (F. Lot, em România, XIX, p. 389, nota 2). O aparecimento inesperado dêsse nome parece corresponder a uma intenção do cronista, que se mostra, aliás, demasiado bem informado para que se possa supô-lo capaz de confusão tão grosseira. 
morto, em combate singular, vários dos mais valentes e nobres cavaleiros franceses, o rei, entristecido, proibiu que daí por diante se aceitassem os desafios do dinamarquês.

Godofredo, conde de Anjou, terido recebido a convocação real, pôsse a caminho, e, tendo chegado a Orleans, recebeu um relatório muito exato acêrca da coragem e das crueldades dêsse dinamarquês. Então, enquanto ordena que suas tropas o vão esperar em Château-Landon, finge ser obrigado a ir a uma conversa secreta, e, sem levar consigo mais que un único homem de armas e dois escudeiros, parte, às escondidas, para Étampes, onde passa a noite. Próbe a seus companheiros de. jornada revelarem a sua identidade. No dia seguinte, continuando a guardar segrêdo, atinge os arredores de Paris e, evitando o burgo de Saint-Germain, vai cncontrar o moleiro que tem sob sua guarda os moinhos do Sena e, tendo-lhe feito uma liberalidade, pede-lhe que se prepare para conduzí-lo ao outro lado do rio sem fazer alarme. Sempre preocupado em não se fazer conhecer, passa a noite em casa do moleiro.

Ao chegar a manhã, atravessa o Sena com o seu cavalo, em barco conduzido por dois moleiros. No momento em que chega à margem direita, avistá o dinamarquês e ouve-lhe os desafios. Estremece, monta, todo armado, a cavalo, e, deixando seus companheiros no barco, atira-se, en tirreno descoberto, sôbre o dinamarquês, que, de seu lado, esporea. sua montada e chega a galope. O conde traspassa o seu adversário. Vendo-o abatido, apeia-se do cavalo, desembainha a espada e corta-lhe a cabeça. Torna a montar, imediatamente, a cavalo, e volta ao barco, trazendo consigo a cabeça do inimigo vencido. Atravessa novamente 0 rio do mesmo modo que o fizera pela manhã e deixa como depósito ao moleiro-barqueiro a cabeça do dinamarquês, a fim de que ês'e a leve à cidade. Depois, ainda em segrêdo, torna a encontrar-se com o seu exército em Château-Landon.

Muitos dos sitiados tinham podido assitir ao duelo através das aberturas das muralhas e dos bastióes, ou do alto das tôrres das igrejas e, sem conhecerem o vencedor, invejavam-lhe o bom êxito. Entretanto, estavam cheios de contentamento, agradeciam a Deus, e ousaran: sair novamente da cidade. Pouco depois, 0 moleirc ao qual fôra confiada a cabeça mostrou-a na cidade e declarou diante do rei que não conhecia nem o nome nem a pessoa do vencedor, por jamais tê-lo visto antes, mis que não duvidava poder reconhecê-lo se o encontrasse novamente. $O$ rei, pensando em outra coisa, calou-se no momento.

Quanto aos dinamarqueses, cheios de dor e tornando-se ainda mais furiosos, pilharam e incendiaram Montmorency, e depois retiraram-se, para tudo devastar, rumo a Senlis, Soissons e até Laon (19).

Vê-se que o cronista torce a história no sentido favorável a suas intençổes, antes carregando-a de pormenores hàbilmente escolhidos que fazendo-lhe violência. Sua arte consiste em dar a impressão de que êle conhece do assunto mais do que disseram os analistas precedentes (20). A indigência das crônicas contempo-

\footnotetext{
(19). - Várias passagens dêste resumo foram tiradas do de W. Cloëta, Les deux rédactions en vers do "Moniage Guillaume", t. II, 1911 , p. 139.141.

(20). - Os sentimentos que podia experimentar em relação a êsses analistas são exprimidos de maneira bastante ingênua pelo cônego de Nantes, que, no cabeçalho de um de seus capitulos (VII, p. 18) em que vai, precisamente, enriquecer c corrigir a seu modo a história, faz a seguinte confidência, para nós muito preciosa: "Os tabeliōes que escreveram os anais que acabo de citar nāo tiveram cuidado algum em narrar os acontecimentos em ordem; ao invés disso, relataram-nos à medida que dêles eram informados: e, como, por preguiça ou negligência, deixaram na sombra tantos fatos dignos do memó ria, nāo merecem em demasia nem elogios, nem censuras". (R. Merlet, La chronique de Nantes, 1896, p. XII).
} 
râneas dos acontecimentos exige complementos, e é, precisamente, o que êle traz. Sabia-se até o presente que o cêrco de París terminara sem que fôsse conhecido o nome do campeão libertador. O historićgrafo da casa de Anjou dá a entender (um moderno caiu nisso) (21) que, se as crônicas anteriores tivessem sido mais completas, se tivessem acompanhado mais longe o curso dos acontecimentos, saber-se-ia, também, que, certo tempo depois dêsse memorável combate, Godofredo Grisegonelle, por ocasião de uma convocação que o fizera ir com outros vassalos do rei a París, foi reconhecido pelo moleiro a quem confiara a cabeça do dinamarquês vencido. "E' aquêle!", grita o homem; "é aquêle, com seu vestuário cinzento, que matou o dinamarquês, que salvou a França da desonra e lançou o terror nas fileiras dos inimigos." Então, conclui o redator dos Gesta consulum Andegavorum, "o rei, com o assentimento de tôda a multidão presente, ordenou que o conde Godofredo se chamasse daí por diante Grisa Tunica (Túnica Cinzenta, Grisegonelle). Eis aí um dêsses "fatos dignos de memória" "deixados na sombra" por êsses descuidosos analistas que se contentavam em relatar os acontecimentos "à medida que dêles eram informados".

De uma construção como a que nos é apresentada por um Tomaz de Loches - que não peca por negligência - pode o historiador colher um ensinamento positivo, quando conhece a finalidade do autor e o seu método de trabalho. Aí se encontram, antes de tudo, indicações acêrca do estado em que se achava a tradição histórica na época da elaboração da lenda. Se o autor de ficções conserva, em sua narrativa, dados históricos que contrariam o seu intento, e cujo efeito só à custa de laboriosos arranjos pode neutralizar, é, certamente, porque é a isso constrangido pelo crédito de que ainda gozavam êsses dados no mundo dos clérigos, e também, talvez, num público mais amplo, que os recebera pela tradição oral. Já se viu que nem o cronista que estava a serviço dos duque da Bretanha, nem o historiógrafo dos condes de Anjou ousaram atacar de frente a tradição que faz do vencedor do combate singular um herói anônimo. Nota-se, do mesmo modo, que, na narrativa da invasão que ameaça París, o autor dos Gesta consulum Andegavorum não pôde deixar de fazer chegar pelo norte, e por via terrestre - embora não fôsse êsse o processo comum dos bárbaros do mar - êsse exército đinamarquês que, em virtude de razões de conveniências dinásticas, êle quis substituir pelo o de Otão II. Também não acreditou que podia ir até o ponto de eliminar de sua narrativa o nome de saxão, inseparável das lembranças da invasão de 978, como o nome de prussiano o devia sê-lo, mais tarde, das lembranças de 1870 . Sentiu, enfim, a impossibilidade de guardar silêncio sôbre as regiões devastadas pelo inimigo, e a obrigação de apontar pelo me-

(21). - Ferdinand Lot alude a issn em Les derniers Carolingiens, 1891, p. 101, nota 1. 
nos as mais atingidas, que eram as de Laon, Soissons e Senlis, que bem sabia estarem diretamente ameaçadas pelos exércitos germânicos, e que haviam sido as primeiras a sofrer, em 978, os efeitos do furor de Otão II. Para neutralizar, porém, a desagradável impressão produzida por êsses três nomes, citou-os (22) na ordem: Senlis, Soissons, Laon, e na parte final de sua narrativa. A fim de poder imputar aos dinamarqueses as devastações espalhadas ao longo da estrada de Alemanha, representa êsses bárbaros indo levar suas assolações para o nordeste, quando, ainda mais enfurecidos (magis in iram efferati) pela morte de seu chefe diante de París, dessa cidade se afastaram cheios de dor e de raiva.

Guardavam-se na França tantas provas da vivacidade das lembranças da invasão de 978 quantàs ainda no tempo em que escrevia Tomaz de Loches. Os que haviam participado da campanha contaram, durante várias dezenas de anos, muitos episódios, e, a partir de suas narrativas, formou-se uma tradição oral que Ferdinand Lot pôde captar muito perto de seu ponto de partida, com o auxílio de um texto anterior de um século à redação de Tomaz de Loches. (23). Os Gesta consulum Andegavorum revelam-nos que, perto do ano 1130 , nas regiões do norte de París, não se haviam esquecido as devastações feitas pela invasão de Otão II tais recordações são das que mais dificilmente se apagam na memória popular - e um cronista que parecesse ignorá-lo teria corrido o risco de perder seu crédito.

Não é apenas por suas ccncessões à verdade histórica que o historiógrafo cortesão nos instrui, é também pelos meios por êle empregados para que se dê crédito a suas ficções. Para dar-lhes um acento de verdade, procura fazer com que, em sua composição, entre o maior número possível de elementos concretos e certos. Os fatos geográficos, cuja evidência ninguém contesta, são os que melhor se prestam para isso. Em geral, porém, são os mais miúdos que emprega; o pormenor topográfico familiar é o seu auxiliar mais comum, nesses tempos em que ninguém ainda percebe claramente, na configuração do terreno, os grandes traços com que os modernos mapas murais nos habituaram desde a infância.

Há, entretanto, nos Gesta consulum Andegavorum no princípio da passagem cujo resumo foi dado mais acima, algo que parece ter relação com um importante elemento da geografia histórica da França: é aquela em que o autor afirma que os bárbaros do mar, dinamarqueses e saxóres (intencionalmente confundidos, ao que parece, pela reunião de anglo-saxão Edilvulfo com o dinamarquês Hastings num único e mesmo personagem) são ligados, por

(22). - Contràriamente aos Gesta pontificum cameracensium, que assinalam bem a direçầo segundo a qual progrediram as devastaçốes: "Primo Remensium, deinde Laudunensium, sed et Suessionensium, novissime vero partes Parisiorum diversa peste vastavit." (M. G. H. SS.., VII, p. 441).

(23). - Cujus expeditionibus Gosfridus Andegavorum comes... interfuit, multique alii nostrae aetatis viri (Geof́roi Grisegonelle dans l'épopée. România, XIX, 1890, p. 392). 
laços de parentesco, aos flamengos. Na época de Tomaz de Loches, ainda se falava, não exatamente em Flandres, mas perto dos limites dessa região, em tôrno de Boulogne e Calais, um idioma saxão trazido, ao tempo das invasões bárbaras, por um povo de marujos, que formara diversos estabelecimentos nas costas gaulesas do Mar do Norte e da Mancha. Um autor do fim de século doze, Lambert, pároco de Arđres-en-Calaisis, diz que, no seu tempo, o Portus Britanicus, isto é, o pôrto do qual se fazia a travessia do Passo de Calais para a Grã-Bretanha, era conhecido pela denominação popular de Witsant (atualmente Wissant) por causa da alvura de sua areia (24). Maisł perto de Calais, um nome tal como Sangate indica a extensão dêsse vestígio lingüístico na direção da planície marítima flamenga. Será que foram as sobrevivências dessas antigas colônias marítimas germânicas do norte da França que deram ao redator dos Gesta consulum Andegavorum a idéia dessa aliança imaginária de seus dano-saxões com os flamengos, aliança de que precisava para justificar o itinerário continental da invasão, traçado, ainda, sôbre o terreno pela lembrança das devastações? Sôbre êste ponto, sua narrativa é demasiado vaga e breve para permitir uma conclusão certa.

Vê-se claramente, em compensação, o seu cuidado em apoiar - que afirma, sempre que possível, em notações topográficas precisas. Penso não existir motivo algum para se contestar sua afirmação de que os invasores acamparam entre Montmorency e París, e fizeram do castelo de Montmorency um dos seus pontos de apôio. Ferdinand Lot propõe que se leia Montmartre em lugar de Montmorency (25). Este nome, porém, é por três vezes citado na narrativa, sob as formas Mons Morentius ou Monmorentius, nenhuma das quais tem o caráter de transcrição inexata. Por outro lado, uma compilação do século doze, originária de Saint-Martin de Tours, o tratado de Senescalcia Franciae (26), contemporâneo dos Gesta consulum Andegavorum, mostra-nos, igualmente, o imperador procurando garantir para si a posição de Montmorency, por ocasião de uma campanha que o leva até as portas de París.

Um exército de invasão que ainda não se apoderou de París não poderia, sem correr os mais graves riscos, estabelecer seus acampamentos entre esta cidade a Montmartre. E' preciso acrescentar que, em 978, Lotário ocupava a margem esquerda do Sena e que um exército germânico instalado ao sul de Montmartre estaria em perigo de ser rodeado pelo norte, com o auxílio do meandro que, rio abaixo de París, leva o leito do Sena até Saint-Denis.

(24). - Britannicum... portum qui ab albedine arenae vulgari nomine appellatur Witsant. Lambert, pároco de Ardres, Chronique de Guines et d'Ardres; edição de Godefroy Niénilglaise, 1855 , p. 27. No Boulonnais, é apenas a partir do sézulo treze que os toponínicos se transmitem de maneira que mostra que nāo são mais compreendidos.

(25) - Notes sur le Moniage Guillaume (România, XXVI, 1897, p. 485, n.0 4). (26): - L. Halphen e R. Poupardin, Chroniques des comtes d'Anjou et des seigneurs d'Amboise, 1913, p. XLIII-XLIV 4239. 
E' natural que Otão tenha procurado garantir uma sólida posição da qual pudesse, dêsse lado, dominar o rio que o separava do seu inimigo, e o castelo de Montmorency estava na posição melhor possivel para lhe oferecer o recurso para isso. O observatório de Montmartre não lhe era menos necessário para a vigilância de $\mathrm{Pa}$ rís e seus arredores. Era, enfim, entre êsses dois pontos de apôio que $o$ terreno se mostrava mais favorável aos acampamentos de seu vasto exército. Nos arredores setentrionais da cidade, era a planície de Saint-Denis que semıre oferecia o espaço necessário para as reuniões de multidões € manobras de exércitos. Foi aí que se fixou, em 1109, o local da grande manifestação religiosa da segunda quarta-feira de junho, de que devia originar-se a feira do Endit (27). Foi aí ainda que, em 6 de abril de 1665 , um viajante italianc, o abade Locatelli, veio ver Luiz XIV cavalgar à frente de trinta mil homens reunidos para a revista geral das tropas (28).

Imagino do modo seguinte a disposição para o estacionamento dos sessenta mil germanos de Otão II diante de París, em 978: o grosso do exército acampa, como as tropas de Carlos-o-Gordc, em 886, por ocasião do cêrco da cidada pelos normandos, por trás do observatório de Montmartre, secundum speculum (29), isto é, ao norte ou a nordeste do outeiro. E' flanqueado pelos destacamentos que, ao norte, guardam a elevação de Montmorency, e, ao sul, a de Montmartre. E é de Montmartre, ponta avançada da formação, que são lançadas sôbre París as manifestações da cólera de Otão II: o campeão, que profere injúrias, e a formidável Aleluia. Para localizar, em duas palavras, tal conjunto, não podia o cronista encontrar melhor expressão que a que reteve: entre Montmorency e París. Também não ponho em dúvida o valor do seu testemunho, quando, pouco mais adiante, assinala que os invasores, antes de baterem em retirada em direção de Soissons, incendiaram a praça de Montmorency, com o evidente intuito de impedir que prestasse acs franceses serviços comparáveis aos que êles mesmos obtiveram.

Deve-se encarar essas indicações precisas como o resgate das infidelidades à história. Quanto mais graves fôrem estas em certas passagens, mais é o autor obrigado a ser exato em outras, para dar à sua narrativa as aparências de auterticidade.

Um bom meio para conseguir-se isto consiste em introduzir na obra pormenores característicos que fazem com que, sem que seja possível hesitação, se reconheçam lugares familiares à maioria de leitores ou ouvintes a quem se dirige o autor. Foi, certamente, o que quís fazer o autor dos Gesta consulum Andegavorum no tre-

(27). - Abade Lebeuf, Histoire de la ville et de tout le diocèse de Paris; edição A. Augier, t. I, 1883 , p. 541 .

(28) . A. Vautier, Voyage de France (1664-1665). Relation de Sébastien Locatelli, 1905, p. 205 .

(29). - Abbon, Le siège de Paris per les Normands, Paris, Les Belles Lettres, 1942.

Canto II, verso 334 . 
cho em que descreve a manobra pela qual Godofredo Grisegonelle conseguiu conservar-se incógnito durante sua curta estada em $\mathrm{Pa}$ rís. À primeira vista, e se nos contentarmos com o resumo feito desta narartiva por $W$. Cloëtta (30), não veremos o interêsse que podia haver em notar que Godofredo Grisegonelle, "tendo chegado perto de París, evita Saint-Germain-des-Prés", porque o seu caminho, a atual rua Saint-Jacques, passa a boa distância dessa igreja. Mas se se tiver o cuidado de consultar o texto, ver-se-á que não se trata da própria abadia de Saint-Germain, e sim do burgo de SaintGermain, burgum sancti Germani (31). Assim se chamava, na Idade Média, não sòmente a aglomeração formada em tôrno da abadia, mas todo o feudo desta, isto é, todo o território sôbre o qual o abade de Saint-Germain-des-Prés exercia os seus direitos de senhoria. A leste, êsse território atingia, pouco mais ou menos, o atual limite do $6 .^{\circ}$ distrito (Vle arrondissement). Estendia-se, com efeito, até à rua d'Enfer e à igreja de Saint-Cosme (na esquina do boulevard Saint-Michel com a rua da École-de-Medicine). Suas extremidades orientais estavam, pois, muito próximas do grande caminho de Orleans (rua Saint-Jacques). Godofredo Grisegonelle, se não quer ser reconhecido, deve evitar êste caminho até ao fim, isto é, até à porta do Petit Châtelet, onde vigia a guarda. E' preciso que êle se desvie pouco tempo antes de chegar ao Sena. Então, porém, deve ter o cuidado de não passar pelo território do burgo de Saint-Germain, onde correria o risco de despertar a atenção dos guardas da abadia. O abade, com efeito, parece ter dado muita importância ao exercício integral dos direitos de alta, média e baixa justiça, que tinha sôbre o seu feudo. Ainda em 1523, fazia com que se inserisse no cartulário um artigo lembrando que, sôbre o burgo de Saint-Germain, o abade e os religiosos têm "todo direito de justiça alta, média e baixa, e, para o exercício desta, o direito de encarregar bailio, preboste, escrivão, policial, deão, carcereiro, guarda de prisões e outros policiais e funcionários da pre. servação de sua dita justiça e direitos senhoriais, e fazer com que usem chibatas, maças e armas necessárias se preciso fôr" (32). A narrativa feita pelo cronista angevino da chegada de Godofredo Grisegonelle a París não tem apenas o interêsse de lembrar-nos que na Idade Média a jurisdição do abade de Saint-Germain-desPrés se extendia até às proximidades da estrada de Orleans; informa-nos, também, de que, na primeira metade do século doze, a polícia do abade tinha a reputação de ser eficiente.

Tendo, pois, o cuidado de não se expor, Godofredo Grisegonelle atinge, na margem escarpada do Sena, a casa de um moleiro. Nos últimos séculos da Idade Média, os moinhos se dependura-

(30). - Les deux rédactions en vers du "Moniage Guiliaume", t. II, 1911, p. 140.

(31). - L. Halphen e R. Poupardin, Chroniques des comtes 'd'Anjou et des seipneurs d'Amboise, 1913 , p. 39.

(32). - A. Berty. Topographie historique du vieux Paris, t. III, Région du bourg Saint-Germain, 1876 , p. 2. 
vam em grande número nos pilares ou nos vigamentos das pontes do Sena. Havia dez, em 1421, sòmente na Grande Ponte (33), que, entretanto, atravessava o braço mais freqüentado pela navegação, e ocupavam ainda mais espaço na Pequena Ponte, que permanecia apartada do grande tráfico fluvial. A abundância de moinhos era, na época, um dos traços que não podiam ser omitidos em nenhuma descrição, por mais breve que fôsse, do leito do Sena em París. Uma canção de gesta do princípio do século treze, que assinala ràpidamente o fato, contém os dois versos seguintes:

Et voient Saine, don parfont sont li gué,

Et les molins, dom il ot planté (34). nele há).

(E vêem o Sena, cujo leito é profundo, e os moinhos que

Os moleiros possuiam barcos para a vigilância e a manutenção de seus moinhos; era-lhes, pois, fácił desempenhar o ofício de barqueiro. Quando se queria atravessar clandestinamente o Sena, evitando-se as portas e as pontes da cidade, procurava-se conseguir as boas graças de um moleiro. Como duvidariam os parisienses do século doze da realidade da história que lhes conta Tomaz de Loches, se nela encontram êste pormenor tão verdadeiro?

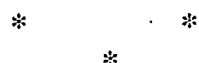

\section{III - A TRANSFIGURAÇÃO POETICA}

A pintura de um ornato contemporâneo, não dos acontecimentos narrados, mas do próprio narrador, adquire mais realce e mais côr em um poema épico do século doze, o Moniage Guillaume, que nos oferece, perto do ano de 1180, a última transfiguração das narrativas históricas que dizem respeito à invasão de 978. Como já se observou, são íntimas as relações entre certos trechos dêsse poema e a hábil narração das proezas de Godofredo Grisegonelle, tal como, meio século antes, o concebera o autor dos Gesta consulum Andegavorum. Há, porém, entre êsses dois trechos, tôda a distância que medeia entre a prosa e a poesia.

Os historiógrafos cortesãos, não obstante seus esforços no sentido de elevar seus senhores ao ápice da glória, não conseguiram elevá-los moralmente acima do humilde soldado de 978, que, diz Richer, logo depois de haver prestado o seu serviço excepcional, foi reclamar a recompensa que lhe haviam prometido. Também êles querem sua recompensa, uma recompensa a seu modo. E a missão do seu historiógrafo consiste justamente em levá-los a

(33). - Delamare, Traité de la Police, t. II, 1713, p. 810.

(34) - H. Suchier, Les Narbonnais, chanson de geste (Société des anciens textes français), t. I, 1898, versos 1874-1875, p. 72 . 
isso, guiando-os através de mil ciladas, que thes estende uma tradição histórica contrária a suas ambiçoes.

O poeta, libertado das sujeições da côrte, atinge, de uma vez, a verdadeira grandeza: se o seu herói permanece desconhiecido, após - combate singular de que saiu vencedor, é porque se esquiva à recompensa. Não a deseja, porque nele se alia a bravura ao desinterêsse de um santo. Quando o rei descobre de quem se trata, êle já se terá afastado muitas léguas da côrte. Cavalgara, já, durante longas horas, em direção à áspera solidão de Gellone, nos arredores de Montpellier, onde, perto de uma capela por êle mesmo construída, leva a existência de um eremita. O lugar chamar-se-á, mais tarde, em sua memória, Saint-Guilhem-le-Désert; com efeito, o homem não é outro senão Guilherme de Orange, um đos principais personagens das canções de gesta, cuja fisionomia épica se libertou das lembranças deixadas por um personagem histórico, Guilherme do Nariz-Curto, morto em Gellone, nos primeiros anos do século nono, após ter-se distinguido nos combates contra os sarracenos.

No poema denominado Moniage Guillaume (isto é, a vida de Guilherme que se tornou monge), a passagem que interessa a $\mathrm{Pa}$ rís principia no momento em que Guilherme de Orange, enclausurado havia já muitos anos em seu retiro de Gellone, onde esperava terminar seus dias em paz, vem a saber que os sarracenos, sob o comando de seu chefe Isoré, cercam o rei Luiz em París. O rei está em grande perigo e deplora que Guilherme não esteja lá, para levar-lhe socôrro. Ignorando, porém, onde êste se encontra, envia à sua procura um cavaleiro, que, após haver inùtilmente percorrido grande número de regiões, dá, ao regressar, desanimadoras notícias. Não conseguiu encontrar Guilherme (na realidade, encontrou-o, sem reconhecê-lo); e até ouviu de um eremita que Guilherme morrera.

Enquanto ém París o desespêto está no auge, Guilherme cavalga, revestido da couraça de duplo tecido de malha, tendo o elmo na cabeça e a espada ao lado. Apartou-se de seu eremitério e retomou seu velho equipamento de guerra para correr em socôrro do rei. Aproxima-se. Ultrapassou Etampes, e ei-lo que chega num domingo, ao cair da noite, diante da porta de París. O vigia proibe-lhe a entrada. Os franceses receiam os espiões sarracenos, e tomam a Guilherme, a princípio, por um dêstes. Deu-se ordem de não se deixar entrar vivalma durante a noite. O rei não suspenderia essa ordem a não ser a favor de Guilherme, mas, infelizmente, bem sabe que não se deve esperar mais revê-lo. Constrangido a passar a noite fora, Guilherme encontra asilo muito perto dos muros da fortaleza da ponte, na cabana de um pobre carregador chamado Bernardo du Fossé. Essa cabana, oculta num fôsso abandonado (donde o nome do seu morador), passou despercebida aos sarracenos e escapou a suas devastações. E' aí que, de manhã cê- 
do, Guilherme ouve as provocações do rei sarraceno Isoré, que se apresenta, como tôdas as manhãs, diante da porta da cidade para insultar os franceses e desafiá-los ao combate. Lança mão de suas armás, sai da cabana, e empenha-se com Isoré em terrivel combate. O vigia, que do alto da torre assiste à cena, alegra-se: lá estão dois sarracenos que se batem, pensa. Guilherme mata a Isoré, corta-lhe a cabeça e trá-la, ainda com o elmo, a seu hospedeiro, Bernardo du Fossé, a quem diz: "Eis a cabeça de Isoré. Guarda-a. Quando os franceses souberem (o que não tardará) que Isoré foi morto, invadirão o campo dos sarracenos e os matarão todos. Em seguida, voltarão a París com imensa prêsa, e certamente, algum dêles se vangloriará de ser o vencedor de Isoré. Desmenti-lo-ás, então, mostrando esta cabeça. Quererão, também, saber quem é o vencedor, mas nada digas." - "Mas se empregarem fôrça para sabê-lo, que deverei dizer?", pergunta Bernardo. - "Pois bem, se te atormentarem, dir-lhes-ás que foi Guilherme de Orange que veio dos desertos da Provença a fim de honrar a corôa da França. E contarás que tive que morar contigo porque não me quiseram deixar entrar em París. Volto agora para penitenciar-me..." Acicata seu cavalo e distancia-se, diante de Bernardo, que se debulha em pranto (35).

Assim é resolvido, com arte que ultrapassa infinitamente a de um Tomaz de Loches, o problema do anonimato do vencedor.

Esse poema completa os ensinamentos que, na exposição ou na exploração de tema análogo, os historiadores e historiógrafos do X, XI e XII séculos já nos deram acêrca de París e sua região. Nota-se, antes de tudo, a narrativa de uma invasão que muito se parece ccm a de 978 . O poeta, aliás, colocou um contingente de dois mil saxões nesse exército que compreendia ao todo sessenta mil homens, a que chama ora de sarracenos, ora de turcos, ora de fersas. Essa multidão lança-se sôbre París, impelindo diante de si uma onda de fugitivos que fazem ao rei espantosas narrativas da crueldade dos bárbaros (é emocionado por essas narrativas que o rei exclama: "Ah! bravo Guilherme, se aqui estivesses, as coisas passar-se-iam de modo muito diferente, e não tardarias em terminar esta guerra"). O chefe pagão, do mesmo modo que, em 978 Otão II, instala seu grande exército diante de París. O poeta não fixa de outro modo o local do acampamento, mas não esquece o observatório de Montmartre, que the dá oportunidade de pintar, em cinco versos, um grandioso quadro:

Et Ysorés, qui Damedieus maudie,

En son Monmartre a s'enseigne drechie.

De Paris voit toutes les manandies,

Et les palais, et les riches iglises,

Et les Franchois, et les gens de la ville (36).

(35). - W. Cloëtta, Les deux rêtactions en vers du "Moniage Guillaume", t. II, 1911,

(36). - Versos 4748-4752. "E Isoré (que Deus o amaldiçoe!) erigiu suas insignias no alto de Montmartre. Vê, de París, tôdas as casas...", etc... 
Por outro lado, muito digno de nota é que um poeta dessa época julgue útil assinalar que essa invasão se desenrolou em paisagem diferente da que vêem os ouvintes a que se dirige: "Senhores barões, diz êle (versos 4680-4690), não sejais incrédulos do que vou dizer-vos. A canção trata de alta antiguidade. Nos tempos de que me ouvis falar, a terra não estava tão cheia de gente quanto hoje, nem tão bem cultivada. Não tinha tantas moradias ricas, não era guarnecida de tantos castelos, nem cidades. Percorriam-se dez ou quinze boas léguas, sem encontrar-se burgo, castelo ou cidade em que se pudesse morar.

\section{Paris estoit a cel jour mout petite."}

Este verso, por si só, revelaria que já estamos longe da alta Idade Média. O poeta percebe a importância do crescimento da cidade desde um ou dois séculos. Pôde adquirir um sentimento muito concreto disso, estudando - pois é evidente que o fêz as narrativas ou tradições referentes ao combate singular de $\mathbf{9 7 8}$. $\mathrm{Na}$ época em que cria sua obra, a porta do Châtelet, em frente da Grande Ponte, năo é mais, como no tempo de Richer, a ponta avançada do sistema defensivo da cidade, do lado do norte. Uma muralha, que ainda não é a de Filipe Augusto, foi, desde então, construída à margem direita, com o fim de encerrar a aglomeração que se formou em tôrno das igrejas de Saint-Jacques-la-Boucherie, Saint-Gervais e Saint-Merri. Conhecemos mal o seu traçado, mas sabemos, pelo testemunho de um autor do século XIV, que uma de suas portas se via na rua de Saint-Martin, bem perto e além da igreja de Saint-Merri. A porta denominava-se, nessa época, Archet Saint-Merri (37). Se o combate singular tivesse sido realizado em 1180, o campeão inimigo, vindo do norte, teria sido detido por essa muralha, antes de haver atingido a ponta da ponte.

Do lado do sul, ao contrário, nada mudara, desde o $\mathrm{X}$ século, no que se refere à disposição geral do sistema defensivo. $O$ subúrbio de Saint-Jacques crescera, sem dúvida, mas ainda não era cercado de muros. Sê-lo-á sòmente no princípio do século XIII. Dêsse lado, pois, era preciso, no século XII, descer-se até - Sena, para se enrontrar os muros de París. A porta meridional da cidade era sempre, como no tempo das invasões normandas, uma porta da ponte. Era o Petit Châtelet, que dominava a entrada da Pequena Ponte.

o Moniage Guillaume, como fonte de informações sôbre a topografia da París do século XII, dá, do combate singular, uma

(37). - Raul de Presles, Traduction de La Cité de Dieu, de Santo Agostinho, em: Le Roux de Lincy e L.-M. Tisserand, Paris et ses historiens aux XIVe et XVe siécles, 1867, p. 109 . 
versão que se distingue pelo fato de situar a ação na margem esquerda do Sena, diante da porta que domina a entrada da $\mathrm{Pe}$. quena Ponte. Tal é, pelo menos, minha interpretação pessoal, cujas razões me vejo obrigado a expor, já que a opinião contrária foi sustentada, principalmente por W. Cloëtta, autor da melhor edição do Moniage Guillaume que possuímos. O meu ponto de vista parece-me ser justificado pela própria descrição que o poeta faz da chegada de Guilherme a París. E' pela grande estrada de Orleans, a atual rua de Saint-Jacques, que êle desce em direçäo ao Sena. Sôbre êsse ponto não é possível dúvida alguma. Como anoitece, apressa-se em atingir a porta da cidade, adiante da "primeira ponte". Cloëtta pretende (38) que essa era a porta do norte, a do Grand Châtelet. Exprime a opinião de que, do mesmo modo que Godofredo Grisegonelle nos Gesta consulum Andegavorum, Guilherme - "embora o autor do Moniage tenha considerado inútil dizê-1o" - "deve ter atravessado e reatravessado o Sena antes e depois do combate". Êsse silêncio que se atribui ao poeta dificilmente se concilia com o caráter da narrativa que, a partir do momento em que Guilherme chega a París, segue o herói passo a passo, e relata o emprêgo do seu tempo com tal precisão que nenhum episódio suplementar poderia inserir-se. $O$ único argumento a favor da interpretação que situa sôbre a margem direita, isto é, diante do Grand Châtelet, a conversa de Guilherme com o vigia, poderia ser tirada de uma passagem do poema, em que vemos Bernardo du Fossé, o pobre homem que deu hospitalidade a Guilherme na miserável casa em que morava, fora dos muros, dela sair, ao anoitecer, para fazer as provisões necessárias à refeição de seu hóspede. Apresenta-se à porta, e o vigia, que bem o conhece, dálhe, não obstante a ordem recebida em contrário, e mediante gorjeta, a permissão de ir à cidade e voltar. Neste trecho da narrativa situam-se os dois versos (5843-5844):

Bernars sen vait la dedens en la cit,

Vers Petit Pont accuelli son cemin.

\section{Ponte). \\ (Bernardo entra na Cidade e toma o caminho da Pequena}

Se se pretende, como Cloëtta e outros, que Bernardo venha da margem direita, é preciso admitir-se que atravessa tôda a largura da cidade, até à Pequena Ponte, para ir fazer compras que não suportam maior demora. Imaginar-se-ia, mais naturalmente, que foi pelo caminho mais curto. E é justamente o que faz, se vem da margem esquerda. Esses dois versos tornam-se muito claros, se as palavras Pequena Ponte aqui tiverem o mesmo sentido

(38). - Les deux rédactions en vers du "Moniage Guillaume", t. II, 1911, p. I81. 
que num poema do princípio do século XIII: a Canção dos Narbonenses, em que se vê um dos mais belos palácios da cidade, bastante amplo para que um enviado do papa e dois arcebispos aí tenham podido morar, está situado "na Pequena Ponte (39)", isto 'é, não certamente sôbre a Pequena Ponte, sem dúvida dômasiado estreita para que nela se pudessem construir palácios dîsse tamanho, com "longos estábulos e grandes celeiros", mas em ' $\mathrm{mm}$ quarteirão próximo à Pequena Ponte e que tinha êste mesmo nome. O Jornal d'un bourgeois de París (40) refere-se, ainda na data de 1416, a açougueiros que vendem carne "na Pequena Ponte". E' fora de dúvida que, na Idade Média, tal denominação aplicava-se não apenas à própria ponte, mas também às regiões vizinhas de suas extremidades.

Outras indicações, fornecidas pelo próprio Moniage Guillaume, convidam ou obrigam a situar sôbre a margem esquerda a porta da cidade diante da qual se apresenta Guilherme, e, por conseguinte, também o casebre de Bernardo du Fossé, bem como o local do combate singular.

Antes de tudo, a própria escolha do personagem de Isoré como adversário de Guilherme. Ferdinand Lot mostrou (41) como se ligou o nome de Isoré a um ponto da margem esquerda do Sena, onde se podia ver, no tempo de Felipe Augusto, um monumento enigmático, que a imaginação popular atribuia aos sarracenos. Era, próximo ao local atual da estação da estrada de ferro de Sceuax, na praça Denfert-Rochereau, um dos túmulos de um cemitério galo-romano, do qual, desde o século XVI se descobriram numerosos vestígios, nas vizinhanças da via romana de Orleans (42). Esse túmulo, qualificado de sarraceno como muitas outras ruínas romanas, era de grandeza pouco comum. Ora, Isoré, no Maniage Guillaume, é sarraceno e gigante. Desde o princípio do século XIII, a identificação do monumento era um fato. Um autor inglês, Gervásio de Tilbury, escrevia entre 1211 e 1214: "Vimos, num subúrbio de París, o túmulo de Isoré, que foi morto por São Guilherme. Seu comprimento é de vinte pés, sem contar a cabeça e a nuca (43)."

Estando o túmulo de Isoré situado à margem esquerda do Sena, era verossímil que o combate singular em que encontrara a morte tivesse sido travado do mesmo lado do rio. Certos críticos, entretanto, julgaram que essa localização do combate dificilmente poderia conciliar-se com a da tenda de Isoré na colina de Montmartre e supuseram que os trechos correspondentes do poema per-

\footnotetext{
(39). - H. Suchier, Les Narbonnais, cFanson de geste, t. I, 1898, versos 2111-2119. (40). - Edição de A. Tuetey, 1881 , p. 74.

(41). - Notes sur le "Moniage Guillaume" (Romania, XXVI, 1897, p. 481-491).

(42). - F. G. de Pachtère, Paris à l'époque gallo-romaine, 1912, 94.

(43). - Otia imperialia em: Leibniz, Scriptores rerum brunsvicesium, 1707, t. $1, p$ 906. - Gervásio de Tilbury quer dizer que o comprimento de vinte pés corresponde
} sòmente ao do cadáver decapitado. 
tencessem a duas redações diferentes. Uma interpretação como essa, a meu ver, não se impõe. Pelas palavras que atribui ao vigia que recebe Guilherme à porta de París, e pela descrição que faz da chegada de seu herói, teve o poeta o cuidado de advertir-nos de que os sarracenos devastam com tôda a liberdade a margem esquerda do Sena, que aí se sentem como se estivessem em sua própria casa, tão bem como na margem direita, a tal ponto que nem mesmo se dão mais ao trabalho de controlar as passagens (verso 5493):

Tant sont sëur, ne se daignent gaitier.

Nenhuma contradição existe entre a situação da tenda de Isoré em Montmartre e sua presença na margem esquerda do Sena, pois que os sarracenos atravessam o tio e a seu bel-prazer, afastando-se, exidentemente, rio acima e rio abaixo, a distância suficiente. No máximo podemos admirar-nos de que, vindo de Montmartre por um desvio bastante longo, Isoré possa ter chegado, desde o amanhecer, diante da porta da Pequena Ponte. Que significaria, porém, esta pequena dificuldade, diante do interêsse que tinha o poeta em situar o duelo não longe dêsse túmulo "sarraceno" que dava à sua narrativa uma ilustração tão surpreendente?

Ferdinand Lot, em suas Notes sur le "Moriage Guillaume", supõe, com bastante verossimilhança, que essa idéia do poeta está na origem da lenda medieval do túmulo de Isoré, de que a atual rua Tombe-Issorire constitui a última lembrança (44).

Se fôsse necessário outro testemunho para desfazer tôdas as dúvidas sôbre a situação da porta diante da qual chega Guilherme, ser-nos-ia dado pelo próprio personagem de Bernardo du Fossé. Qualifiquei-o, há pouco, de carregador. Do ofício de Bernardo, porém, dá o poeta uma definição mais precisa, que está nas palavras que o vigia dirige a Guilherme a fim de indicar-lhe um lugar em que poderá pernoitar (versos 5583-5598): "Bem ao lado daqui, atrás dêsse grosso muro, há um velho fôsso abandonado (45). Aí mora um pobre homem, que, todos os dias, leva achas de lenha ao mercado. Nesse lugar fêz uma cabana, porque não pode habitar na cidade: nesta não se tolera gente pobre, que não tem com que prover ao seu sustento. Por todos os arredores; não há muita gente. Os massacres e tormentos despovoaram o lugar. Esse homem, porém, escondido em seu fốsso, esıapou. Dépois de descarregar dos ombros as achas de lenha que leva à cidade, e receber algumas moedas em paga de sua lenha, compra pão e o que the

(44). - Romania, XXVI, 1897, p. 491.

(45). - A presenca de rossos abandonados nas vizinhanças de uma porta de cidade devia ser coisa comum nessa ́́poca. Ao aproximar-se um ataque inimigo cra habitual completar as defesas permanentes das portas por entrincheiramentos avançados, cujo vestigio podia perdurar nuito tempo depsis de passado perigo. 
é necessário, depois volta para ir deitar-se em sua casa. Ide, pois, passar esta noite em casa dêle."

Ora, documentos do século treze mostram-nos que, bem perto da extremidade sul da Pequena Ponte, ao longo da margem escarpada do Sena, estavam instalados vendedores e carregadores de lenha (46). A parte da Pequena Ponte em que se concentravam é assinalada, em um documento de 1219 , pelas palavras buscheriam parvi pontis (47), o lenheiro da Pequena Ponte. A relação dos contribuintes do impôsto da talha de París, em 1292, menciona, na rua de la Bucherie, um "buchier", isto é, um mercador de lenha, que é tributado em dois soldos, e, não longe dêle, um "atiréeur de buche", carregador de lenha, que é taxado com o mais baixo impôsto (12 dinheiros) (48). Bernardo du Fossé, na canção de gesta, é um dos mais pobres carregadores de lenha. Mora, como diz exatamente o vigia a Guilherme, bem perto da porta da Pequena Ponte, - e rio acima, poder-se-ia acrescentar, - se, como é lícito pensar, a proveniência da lenha para aquecer trazida a París pelo Sena era, "já no século XII, a indicada nos documentos do século XV. Uma ordem de 1415 , relativa à venda de lenha para aquecer trazida a París pelo Sena, e que menciona, entre os principais pontos de chegada, o "lenheiro de Pequena Ponte", declara que tal comércio é livre para os mercadores "que fazem vir a lenha, qualquer que seja, da parte superior do rio, a saber, do lado da Borgonha, Champagne ou outros lugares acima das pontes de París", não, porém, para "aquêles que a trouxerem ou fizerem vir da parte inferior dọ rio" (49). Por isso, êsse "lenheiro de Pequena Ponte" situava-se imediatamente acima da Pequena Ponte, que, obstruída pelos moinhos, assinalava o ponto final dos transportes provenientes da parte superior do rio. Acêrca do destino dêsse lenheiro, Delamare, em seu Traité de la Police, dá-nos, no fim do reinado de Luiz XIV, as seguintes informações: "Não havia, outrora, em París, senão os portos da Grève e de la Bucherie, próximo ao Petit Châtelet, para a chegada e venda da lenha que vinha de rio acima... O pôrto do lenheiro foi suprimido há muito tempo; a rua conservou-lhe o nome (50)".

Eis, após a Tombe-Issoire, - respeitamos essas velhas denominações- outro nome de rua que nos vem em linha reta dos tempos em que foi construído êsse nobre monumento de arte me-

(46). - Existia, ainda, no século XVII, em París, a corporação dos "carregadores de lenha trazida pelo rio", que reunia parte importante dos empregados no transporte de fardos $\mathrm{cm}$ portos fluviais. ( $\mathrm{H}$. Saudal, Históte ét recherches des antiquités de la ville de Paris, t. I, 1724, p. 26).

(47). A. Berty, Tisserand et Platon, Topographie historique du vieux Paris, $t$ VI, Région centrale de l'Universifé, 1897, p. 25.

(48). - H. Géraud. Paris sous Philippe le Bel, 1837, p. 151, col. 2.

(fo) - Delamare, Traité de la Police, t. III, 1719 , p. 844.

(50). - Delamare, Traité de la Police, t. III, 1719, p. 841, col. 2 . 
dieval a que chamamos Moniage Guillaume, do qual ignoramos o autor... também anônimo.

Nessa obra opera-se como que um derradeiro desabrochar dos sentimentos que, em tôrno e depois delas, suscitaram as narrativas históricas da alta Idade Média, dominadas pela evocação do grande combate contra os pagãos. París, nessa época, "era mui pequena", e se, nessas narrativas, se revestiu de tanta importância, não foi como capital, mas como praça de guerra que tanto se opunnha às invasões navais que procuravam subir o rio, quanto às invasões terrestıes, que, vindas do Norte, procuravam transpô-lo para atingir o centro do país.

Já no fim dêsse século XII, no qual se fixa, em París, a lenda de Isoré, estamos no comêço de um período em que a alma francesa vai encontrar, no poderio da monarquia, outros motivos de entusiasmo; em que vão aparecer obras literárias de novo caráter, que celebrarão a cidade por ela mesma, e nela exaltarão, ao mesmo tempo, a capital e o foco de civilização.

\section{ROGER DION}

Professor do Colégio de França. 